\title{
The Impact Of Social Media As Promotion Tools Towards Intention To Visit: Case Of Batu, Malang, Indonesia
}

\author{
Amir Hidayat ${ }^{1}$ and Robert La Are $^{2}$ \\ ${ }^{1,2}$ Swiss German University, Tangerang, Indonesia \\ Email : 'hidayat.amir30@gmail.com and ${ }^{2}$ robert.are@sgu.ac.id
}

\begin{abstract}
This research aims to investigate the positive impact of social media as promotion tool toward intention to visit, case of Batu, Malang, Indonesia. Social media is user-generated content as the independent variable, and intention to visit, or intention which means the motivation of a person in the sense of his or her effort to accomplish their cause, it stands as the dependent variable. Quantitative methods is used as research method and using simple linear regression model as data analysis followed by sampling technique using a purposive sampling. Data collected through the questionnaire where 110 respondents that uses social media with 15 items of statement. Based on the data that has been processed, it shows that social media is positively impact intention to visit in Batu, Malang.
\end{abstract}

Keywords- Social media, Promotion, Intention to visi, Batu, Malang, Indonesia

\section{INTRODUCTION}

Batu is a city located in East Java, Indonesia which is surrounded by mountains, 800 meters above sea level with average temperature around 17 to 25,6 degre Celsius, which is quite cold considering Batu is located in Indonesia which is geographically considered as a tropical country (East Java, 2015). Population in Batu reaches 211.298 in 2014 with 1.15 percent average growth from 2012 with 194.793, and population density reaches 1,060 per kilometer.

Batu is also identic with its tourism sector, even since the Dutch colonial era, Batu is already got a special name from the Dutch as De Klein Switzerland, and now Batu city is also called "Batu City, A Millions Beauty" for their numerous natural attractions such as Coban Rondo waterfall, Mount Panderman, Mount Arjuno, Mount Welirang, Mount Ukir and Mount Banyak (East Java, 2015).

For Batu, tourism held a crucial role to their economy since $65 \%$ of their local government income came from tourism, which is equivalent to 30 billion rupiahs in 2012 (Batu News; Bisnis.com, 2012).

According to Batu Tourism Board statistic that has been gathered by Intyaswono, et al., (2016) the number of visitors that came to Batu have grown slowly year by year since 2011 to 2014 which will be shown on table 1.1 below. 
TABLE I. TOTAL NUMBER OF VISITOR

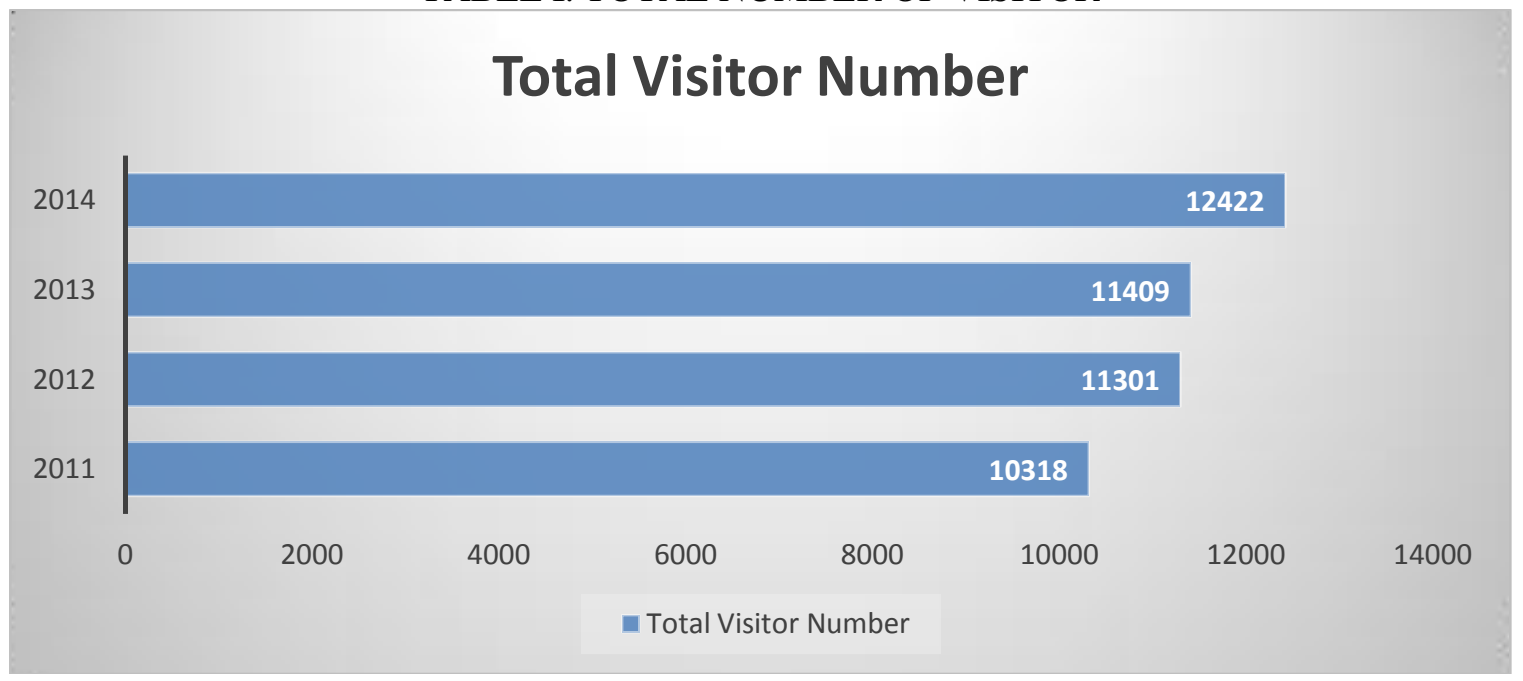

(Source; Intyaswono, 2016)

By reflecting to this numerical data that has been gathered, it shows that Batu has a good potency as a tourism destination according to the visitor purposes that came there for leisure became the top reason why they came there in the first place (Intyaswono, et al., 2016).

However, according to Surya Malang (2016), despite of being a quite successful tourism destination, Batu, Malang tourism board receiving complains from the local business owners regarding the promotional effort that has been done, the local business owners assume that it is better to have a promotion board that specifically made for promotional matter to effectively increase public awareness upon Batu, Malang as a tourism destination. Discuss about tourism destination promotion, many of tourism destination was promoted through social media such as Instagram, Twitter, or Tourism destination website based on mobile application. Nowadays social media is become one of the important things in this era, since the social media has covered short and strive information about the product itself, also offer complete and innovative contents. Batu, Malang is start to use social media as one of their promotion tools since 2015, by providing certain information such as mobile application called "Shining Batu" which will be shown on figure I bellow.

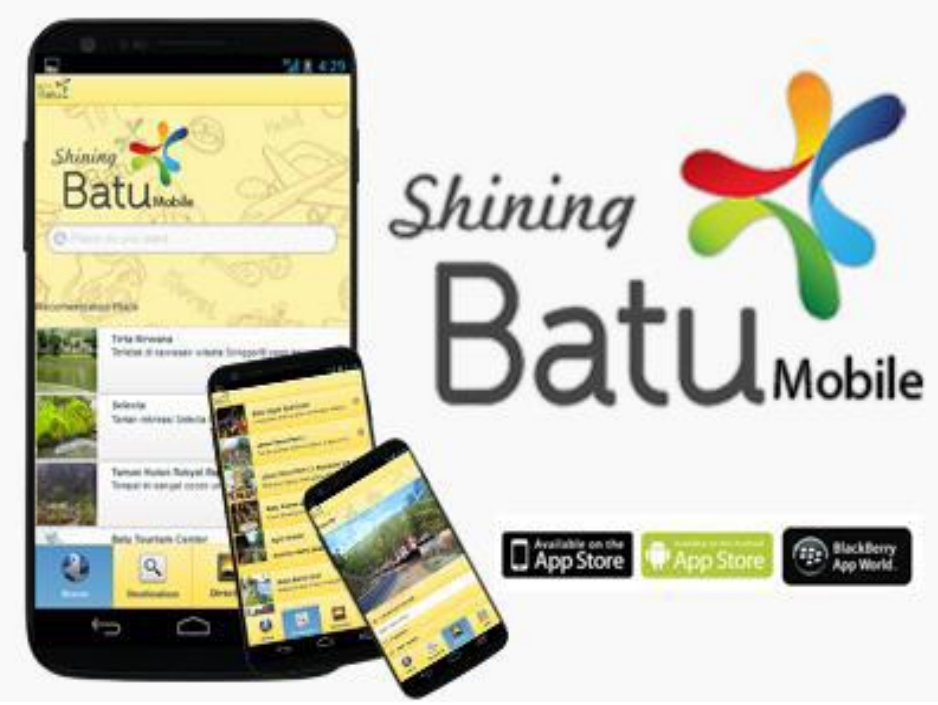

(Source; Intyaswono, 2016)

Fig I. Shining Batu Mobile Application 


\section{LITERATURE REVIEW}

\section{A. Framework of thinking}

\begin{abstract}
Symptom:
BatulMalang, Indonesia as a growing tourism spot does not have a tourism promotion board according to Surya Malang (2016)

Social media user has the power to acquire and give or even manipulating information around whether its promoting or even negatively influence people's opinion through non-formal communication messages. (Sweeney \& Craig, 2011)
\end{abstract}

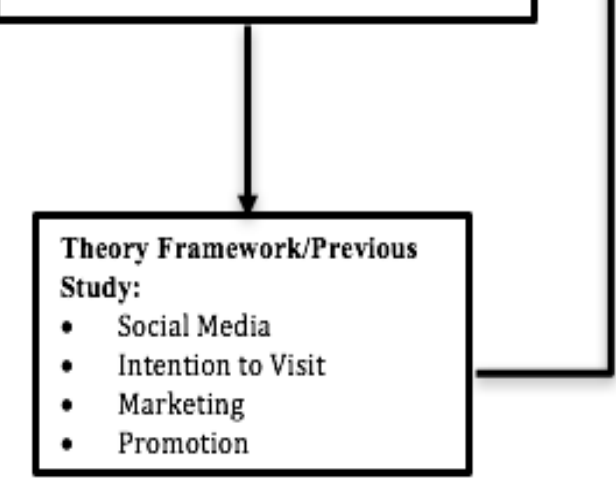

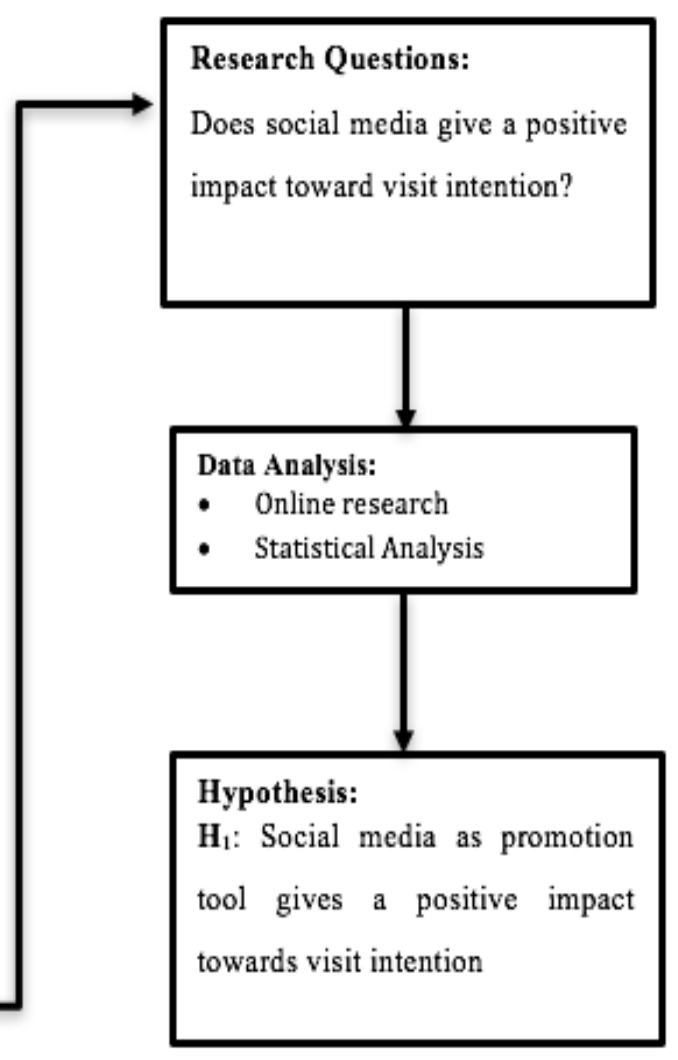

Fig II. Research Framework

\section{B. Social Media}

The Origin of social media dates to the earliest content of all which was called Web Version One. This Web Version One is a static content, as the description stated, static content means the viewer or audience at that time could not participate in editing the website content, unless they are the ones who are web developers that have the obligation to modify and update the webpage.

Then the next version which was called Web Version Two from approximately twenty years ago, started to emerge as open diary. Now the audience knows this as social networking. One year often the open diary emerged, the users came up with the new term, by changing the word web-log to we blog, and now people call it blog(Kaplan \& Haenlein, 2010). Then years later, in between 2003 to 2004, another kind of social networking emerges, namely My Space and Facebook (Eason, 2007). The time these two dominators emerged, it proclaims the beginning of world of creation (Wells, 2008).

People were once being a loyal receivers or silent audience of static content, now they could consider themselves as co-creators with the profound freedom to interact, publish, critique, and build relationships with fellow users through the platform (Tuten, 2008). Alexander \& Levine (2008) also stated what makes web version two different from its ancestor is that web version two have two essential features which are micro content and social media. These are possible with the web version two which is dynamic, interactive, and collaborative which encourages people's participation in the generation of creation. (Warschauer \& Grimes, 2007; Chan \& Guillet, 2011). 


\section{Influence of social media}

To start with there are tons of information circulating around the online network which are available to the user of Web Version Two with varieties of forms, such as texts, pictures, audio, and videos across the network. In this case, social media is considered as one of the products of Web Version Two which grants the user the power to acquire and give or even manipulating information around whether its promoting or even negatively influence people's opinion through non-formal communication messages.

This situation is possible since social media gave them the opportunity of high exposure to a complex and combined form for transmitting information with ease. Then it also affects some varieties of brands, products, services, places, environments, political, economic and social because now people could express their opinion regarding those related topic (Sweeney \& Craig, 2011).

Sweeney \& Craig (2011) mention there are four important pillars that affect the success rate of communication through social media, which are:

1. Establish effective communication with the customer.

2. Collaborating with the customer.

3. Make effort in educating the customer.

4. Assuring the customers were entertained.

These pillars were made with a purpose for promoting the product and services effectively and efficiently. To make sure its effective, being trustworthy and consistent regarding the content that has been published is essential in establishing a strong relationship with the audience because mere word of advert does not work for long run ventures (Vasiliu, 2007).

\section{Types of social media}

The advancements in technology especially with the beginning of Web Version Two that occurs in this modern time took part in the growth of social media which makes it very important in matters of marketing a tourism destination (Chan \& Guillet, 2011; Goeldner \& Ritchie, 2012), there are several types of medium of social media that will be described below:

1. Blogs is described as formal journal, diary, or news letter that published on websites, which also considered the early form of web version two that allows blogger or users to upload textual entries, images, hyperlinks, videos or other interactive media to online format. This form of Web Version Two could be considered as social media due to the case that it allows the user to interact with each other through posting a comment or subcribtion, which is the core essense of social media, user generated content and accommodate two way communication between user (Kennedy, et al., 2007)

2. Social Networking is a personal website that exist within a larger network where user is encouraged to connect to each other in effort to form a community (Kennedy, et al., 2007; Eason, 2007)The signature traits of social networking includes using profiles, personal pages, photos and messages to enhance the connection between users (Goeldner \& Ritchie, 2012)

3. Content Communities, the purpose of this kind of social media is to give the user the ability to share media content among users (Goeldner \& Ritchie, 2012).

\section{E. Social media measurement}

In matters of examining this user generated content (social media), AMEC (2013) or international association for the measurement and evaluation of communication published a designated framework for examining social media. This framework is called social media measurement standard conclave which consists of exposure, engagement, influence, impact and advocacy.(AMEC, 2013;Theaker, 2016). The framework will be presented below in figure III : 


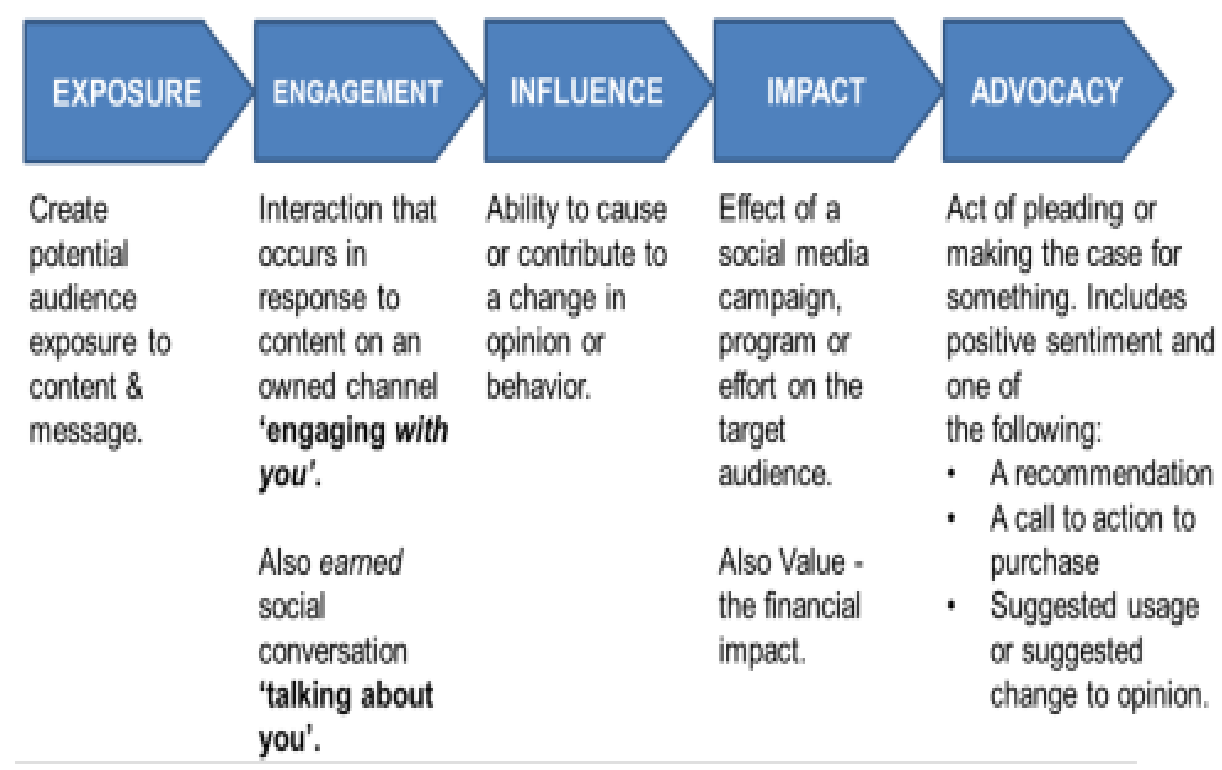

Source; Theaker, 2016

Figure III. AMEC Social Media Measurement

\section{F. Intention to visit}

The main goal of common travel marketing strategies is basically to amplify the number of visitors to a destination that has been chosen and increase the probability (Hennessey, et al., 2016). Gärling, et al.,(1998) define the word intention as the motivation of a person in the sense of his or her behavior towards their plan in effort to execute it.

Besides having the decision-making process within making a purchase, intention happens where customer trying to decide whether to buy within a certain situation, when usually this intention directly related to the customer behavior, perceptions and attitude (Mirabi, et al., 2015;Shah, et al., 2012). The process also consists of having the ability to access and evaluate the product by the potential customer in means of purchasing a product (Milhinhos, 2015).

In matters of measuring intention to visit. Hennessey, et al., (2016) had tested these phenomena using these indicators:

1. Advertising recall

2. Number of media sources recalled

3. Number of visits to the website

4. Type of information searched

5. Satisfaction with the website

Moreover, personal and social determinants of travel behavior also take part on the consideration which includes socioeconomic status, personality features, social influences, and attitudes and values, and external variables which includes:

1. Confidence,

2. Image of destination,

3. Past travel experience,

4. Assessment of objective/subjective risks,

5. Constrains of time and cost.

These points play an important role in creating awareness, which influencing travel intention and selecting accommodation, destination, activity, attraction, transportation mode, route, shopping and eating (Hennessey, et al., 2016). 


\section{G. Research Model}

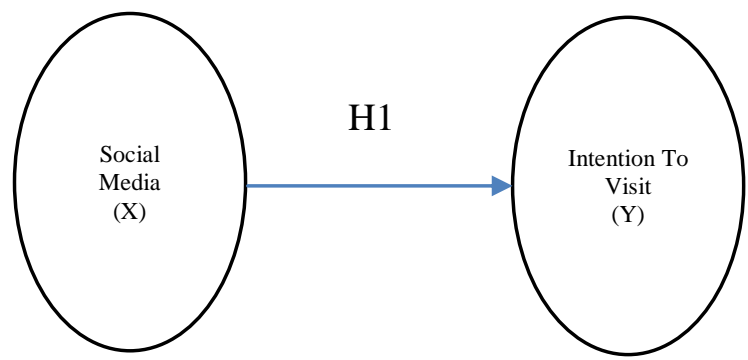

Fig IV. Research Model

$\mathbf{H}_{1}$ : Social media as promotion tool gives a positive impact towards visit intention

$\mathbf{H}_{\mathbf{0}}$ : Social media as promotion tool does not give a positive impact towards visit intention

\section{METHODS}

The scope of this study is focused in Indonesia focuses on social media user. Through this scope of study the author will gain the clear limit of how wide this research should be conducted to avoid dull analysis due to wide range of data.

\section{A. Population \& Sampling}

Population could be defined as a variation group of people that examine as an indicator or representative of a larger sample size (Brotherton, 2008) that used for a certain research purposes. In this case, the population is unknown and the sample for this research are people that uses social media. These samples came from variety of demographic profiles that uses social media (Thompson, 2012).

Sampling method that has been chosen by the author is purposive sampling, which in description that this technique allows the author to collect data from a population that have some common traits among them or special characteristic that they posse (Thompson, 2012). The characteristic that the author chooses population that uses social media.

The equation for determining the minimum sample size for this research are presented below:

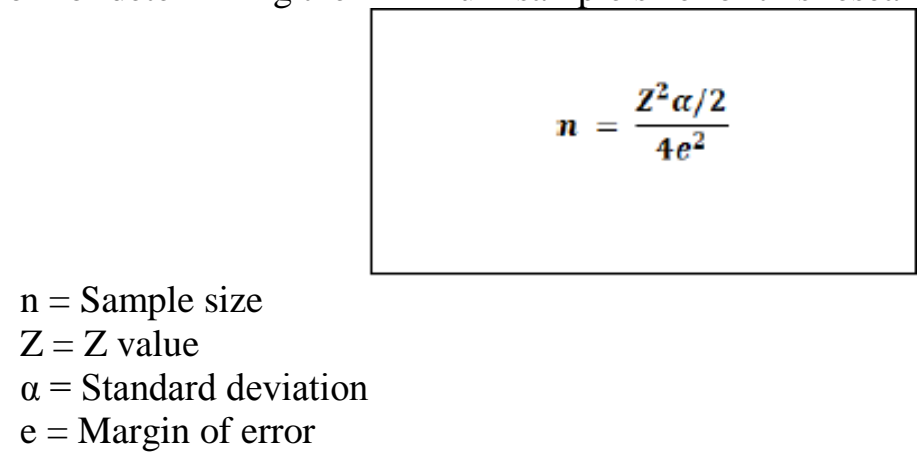

Where the calculation are :

$$
\begin{gathered}
n=\frac{1.645^{2}}{4 \times(10 \%)^{2}} \\
n=\frac{2.71}{4 \times 0.01} \\
n=67.65 \sim 68
\end{gathered}
$$

(Source; Wibisono Formula) 


\section{B. Operational variable}

The operational variable in this research were social media (as variable $\mathrm{X}$ ) and intention to visit (as variable Y). The indicators of social media is exposure, engagement, influence, impact, and Advocacy. Meanwhile, the indicators from intention to visit is advertising recall, number of media recalled, number of website visitors, number of information searched, and satisfaction with the website (Sekaran \& Bougie 2014) as shown on the table below;

Table II. Operational Variable

\begin{tabular}{|c|c|c|c|c|c|}
\hline \multirow{2}{*}{$\begin{array}{l}\text { Variable } \\
\text { Social media }\end{array}$} & \multirow{2}{*}{$\begin{array}{l}\text { Indicator } \\
\text { Exposure }\end{array}$} & \multicolumn{4}{|c|}{ Statements } \\
\hline & & $\begin{array}{l}\text { I want to visit Batj, Malang, } \\
\text { Indonesia because I saw related } \\
\text { content or promotion on social media }\end{array}$ & $\begin{array}{l}\text { Social } \\
\text { media } \\
\text { affect my } \\
\text { Impression } \\
\text { on Batu, } \\
\text { Malang, } \\
\text { Indonesia }\end{array}$ & $\begin{array}{l}\text { Number of Batu, Malang content on social } \\
\text { media affect my intention to visit Batu, } \\
\text { Malang Indonesia. }\end{array}$ & Ordinal \\
\hline & Engagement & $\begin{array}{l}\text { After I saw promotion and social } \\
\text { media content of Batu. Malang, } \\
\text { Indonesia, it motivates me to interact } \\
\text { and discuss through comments, likes } \\
\text { and shares }\end{array}$ & \multicolumn{2}{|c|}{$\begin{array}{l}\text { Hashtag helps me to search for information regarding Batu, } \\
\text { Malang, Indonesia }\end{array}$} & Ordinal \\
\hline & Influence & $\begin{array}{l}\text { After I saw some promotion and } \\
\text { social media content of Bats, } \\
\text { Malang, Indonesia, I'm motivated to } \\
\text { search for some reliable reviews }\end{array}$ & $\begin{array}{l}\text { Reviews on } \\
\text { social } \\
\text { media } \\
\text { affect my } \\
\text { perception } \\
\text { of Batw, } \\
\text { Malang, } \\
\text { Indonesia }\end{array}$ & $\begin{array}{l}\text { Social media reviews affect my } \\
\text { consideration to visit Batu, Malang, } \\
\text { Indonesia }\end{array}$ & Ordinal \\
\hline & Impact & \multicolumn{3}{|c|}{ Social media content motivates me to promote about Batu, Malang, Indonesia to my friends } & Ordinal \\
\hline & Advocacy & \multicolumn{3}{|c|}{ Social media user's recommendation affect my intention to Batu, Malang, Indonesia. } & Ordinal \\
\hline \multirow[t]{5}{*}{$\begin{array}{l}\text { Intention to } \\
\text { visit }\end{array}$} & $\begin{array}{l}\text { Advertising } \\
\text { recall }\end{array}$ & \multirow{2}{*}{\multicolumn{3}{|c|}{$\begin{array}{l}\text { Some various type of media that has been chosen to advertise and promote of Batu, Malang, } \\
\text { Indonesia tourism positively affect my intention to visit }\end{array}$}} & Ordinal \\
\hline & $\begin{array}{l}\text { Number of } \\
\text { media } \\
\text { sources } \\
\text { recalled }\end{array}$ & & & & Ordinal \\
\hline & $\begin{array}{ll}\text { Number } & \text { of } \\
\text { visits } & \text { to } \\
\text { website } & \end{array}$ & \multicolumn{3}{|c|}{ Visiting Batu, Malang tourism website positively affect my intention to visit } & Ordinal \\
\hline & $\begin{array}{l}\text { Number of } \\
\text { information } \\
\text { searched }\end{array}$ & \multicolumn{3}{|c|}{$\begin{array}{l}\text { Various of information that I have found regarding Batu, Malang is informative and positively affect } \\
\text { my intention to visit }\end{array}$} & Ordinal \\
\hline & $\begin{array}{l}\text { Satisfaction } \\
\text { with the } \\
\text { website }\end{array}$ & \multicolumn{3}{|c|}{ I'm satisfied with content which presented on Batu, Malang tourism website } & Ordinal \\
\hline
\end{tabular}

Source; modified by author

\section{Simple Linear Regression}

Simple linear regression method was used for data analysis. Studenmund, 2006, stated that regression analysis is a statistical technique that attempts to "explain" movements in one variable. Linear regression observation of $\mathrm{X}$ values to estimate or predict corresponding $\mathrm{Y}$ values (Cooper \& Schindler, 2014). Linear regression may be expressed as below equation.

$$
\begin{array}{ll}
\mathbf{Y}= & \boldsymbol{\beta}_{\mathbf{0}}+\boldsymbol{\beta}_{\mathbf{1}} \mathbf{X} \\
\mathrm{Y} & : \text { dependent variable } \\
\mathrm{X} & : \text { independent variable } \\
\beta_{0} & \text { : constant or intercept } \\
\beta_{1} & \text { : slope coefficient }
\end{array}
$$

\section{Classical assumption test}

The purposes of classical assumptions test is to minimize any error within the data collected that might affect the final results. For the simple linear regression, the author using normality test and heteroscedasticity test. 


\section{Normality Test}

Normality test is conducted to find out the residual distribution from sets of data. Good sets of data have a normal residual distribution; this test is possible by using Kolmogorov-Smirnov (K-S). Data are normal if its residual values are above significance values set or it can be said if $\mathrm{P}$ value $\geq \alpha$, h0 is accepted, data are normal. However if $\mathrm{p}$ value $<\alpha, \mathrm{h} 0$ rejected it means data are abnormal (Sunjoyo et al, 2013).

\section{Heteroscedasticity Test}

Heteroscedasticity is known as a situation where the conditional variance of the Y population varies with $X$. Glejser test can be used to detect heteroscedasticity. If $P$ value $\geq \alpha, h 0$ is accepted, data are free from heteroscedasticity, in the other hand if $\mathrm{p}$ value $<\alpha, \mathrm{h} 0$ rejected, it means data contains heteroscedasticity (Sunjoyo et al, 2013).

The result needs to be a constant variance of independent variable. Further analysis will be called Glejser Test, which uses for this research, and to assess this result (Widodo, 2017), there is a hypothesis as the following:

$\mathrm{H}_{0}$ : The data does not contain heteroscedasticity.

$\mathrm{H}_{1}$ : The data contains heteroscedasticity.

The data is free from heteroscedasticity if the significance value from the analysis result is greater than or same with the significant level $(\alpha)$.

\section{$\underline{H}_{0}$ accepted if: \\ $P \geq \alpha, P$ : Significance value $\alpha$ : Significant level}

\section{RESULT AND DISCUSSION}

\section{A. Classical Assumption Test}

\section{Normality Test Result}

Normality test purpose is to detect whether the residual value is distributed normal. The statistical hypotheses for normality test are:

$\mathrm{H}_{0}$ : Data is normally distributed

$\mathrm{H}_{1}$ : Data is not normally distributed

Later, the asymp.sig value will be compared to desired level of significance which in this case 0.05. If it is higher than $0.05, \mathrm{H}_{0}$ is accepted. Author will use One-Sample Kolmogorov-Smirnov among several normality tests. The results of normality test can be seen below, on table III

TABLE III. NORMALITY TEST RESULTS.

One-Sample Kolmogorov-Smirnov Test

\begin{tabular}{|ll|r|}
\hline \multicolumn{2}{|c|}{ One-Sample Kolmogorov-Smirnov Test } \\
\hline $\mathrm{N}$ & $\begin{array}{c}\text { Unstandardized } \\
\text { Residual }\end{array}$ \\
Normal Parametersa,b & Mean & 110 \\
& Std. Deviation & .000000 \\
Most Extreme & Absolute & 1.79771890 \\
Differences & Positive & .068 \\
& Negative & .068 \\
Test Statistic & & -.067 \\
Asymp. Sig. (2-tailed) & .068 \\
\hline \multicolumn{2}{|c|}{ Table 24 Kolmogorov-Smirnov test results } \\
\hline
\end{tabular}

a. Test distribution is Normal.

b. Calculated from data.

c. Lilliefors Significance Correction.

d. This is a lower bound of the true significance.

The Data Asymp sig value is 0.200 , which means the data is normally distributed. 


\section{Heteroscedasticity Test Result}

This test is aim for a homogeneous answer from its respondents. Heteroscedasticity is a test to determine whether the answer from respondent is homogenous or not. It does not mean that the answer cannot be varied, however their variation should be still in the range of standard deviation. The statistical hypotheses of heteroscedasticity test are:

$\mathrm{H}_{0}$ : Data do not contain heteroscedasticity

$\mathrm{H}_{1}$ : Data contain heteroscedasticity

Researcher will aim for $\mathrm{H}_{0}$ being accepted. In order to accept $\mathrm{H}_{0}$, the value of sig should be higher than 0.05 (level of significance). The result of heteroscedasticity test can be seen from table IV

Table IV. Heteroscedasticity Test Result

\begin{tabular}{|c|c|c|c|c|c|c|}
\hline \multirow[b]{2}{*}{ Model } & & \multicolumn{2}{|c|}{$\begin{array}{c}\text { Unstandardizod } \\
\text { Cocfficientis }\end{array}$} & $\begin{array}{l}\text { Standardized } \\
\text { Coefficicints }\end{array}$ & \multirow[b]{2}{*}{$\mathrm{T}$} & \multirow[b]{2}{*}{ Sig. } \\
\hline & & $\bar{B}$ & Stat. Error & Beta & & \\
\hline 1 & (Constant) & 2.468 & .726 & & 3990 & \\
\hline & Social Media $(X)$ & -0.027 & .017 & -148 & -1.560 & .12 \\
\hline
\end{tabular}

The significant value is exceed than 0.05 which means the data is proven to be nonheteroscedasticity.

\section{Hypothesis Testing}

The Social Media have sig value of 0.000 . In order for $\mathrm{H}_{1}$ to be accepted, the sig value should be less than alpha (0.05). The results for t-test can be seen on table below:

Table V. Hypothesis Testing Coefficient.

\begin{tabular}{|c|c|c|c|c|c|}
\hline \multirow[b]{2}{*}{ Model } & \multicolumn{2}{|c|}{$\begin{array}{c}\text { Unstandardized } \\
\text { Coefficients }\end{array}$} & \multirow{2}{*}{$\begin{array}{l}\text { Standardized } \\
\text { Coefficients }\end{array}$} & & \multirow[b]{2}{*}{ Sig. } \\
\hline & B & Std. Error & & & \\
\hline (Constant) & 1.910 & 1.117 & & 1.711 & .090 \\
\hline 1 Social Media (X) & .316 & .026 & .757 & 12.031 & .000 \\
\hline
\end{tabular}

a. Dependent Variable: Total Intention to Visit

If the Sig. value is $>\alpha(\alpha=0.05), \mathrm{H}_{0}$ is not rejected, $\mathrm{H}_{1}$ is rejected If the Sig. value is $<\alpha(\alpha=0.05), \mathrm{H}_{0}$ is rejected, $\mathrm{H}_{1}$ is not rejected.

As shown in highlighted of sig above which means the hypothesis that has been proposed for this research is accepted.

Table VI. Adjusted R. Square Result

\begin{tabular}{|l|c|r|r|c|}
\hline Model & \multicolumn{1}{|c|}{$\mathrm{R}$} & R Square & \multicolumn{1}{c|}{$\begin{array}{c}\text { Adjusted } \mathrm{R} \\
\text { Square }\end{array}$} & $\begin{array}{c}\text { Std. Error of the } \\
\text { Estimate }\end{array}$ \\
\hline 1 & $.757 \mathrm{a}$ & .573 & .569 & 1.806 \\
\hline
\end{tabular}

\section{a. Predictors: (Constant), Social Media (X) \\ b. Dependent Variable: Intention to Visit (Y)}


Adjusted R square was used to determine how much percentage that the independent variable affect the dependent variable. According to the table above, it shows that social media as independent variable positively affect intention to visit as dependent variable for $56.9 \%$.

\section{B. Discussion}

Based on the result, some of the theory or claims from previous studies that has been addressed on chapter two could be re-validated. According to Balakrishnan, Dahnil, and Yi (2014) feedback or reviews from social media could increase their purchase intention or in this case intention to visit, by having these result, Balakrishnan, Dahnil and Yi (2014) claim is re-validated. Abzar, Ghassemi and Vosta (2014) mention that social media can influence customer's decision on purchasing, but in this study, it's not matter of purchasing instead its matter of intention to visit. based on the result that its proven that social media impact the intention to visit which also validates the previous studies findings.

In this studies results it shows that social media gave an impact to intention to visit through the visitor by $56.9 \%$, which validates the previous studies claimed as hypothesis are accepted. Social Media has play a significant role and become potential promotion tools. Királová and Pavlíčeka (2014) states that through social media it gave the visitors power to involve in attracting potential visitors to the destination, by providing or even manipulating information around whether its promoting or even negatively influence people's opinion through non-formal social media communication (Sweeney \& Craig, 2011). Odhiambo (2012) on the other hand found that social media cannot be effective and self-sustain without the support from other traditional media channels, which connected to the result of this study that indicates that social media affect $56.9 \%$ in matter of intention to visit, then the missing piece or $43.1 \%$ could possibly be another traditional media to complete the whole picture of promotional matter. Which also supports numerous of author that mentioned that some of the factor or stimulation that affect intention to visits is advertising or promotion which could be through social media or traditional media (Burke \& Gitelson 1990; Kim, Hwang, \& Fesenmaier 2005; McWilliams \& Crompton 1997; Messmer \& Johnson 1993; Woodside 1996).

\section{CONCLUSION}

Through this study, it is proved that social media as a promotion tool influences intention to visit to Batu, Malang, Indonesia on the level of 56.9 percent based on the adjusted R-square result in chapter 4 . This conclusion has proven that social media as promotion tool affect intention to visit, even though there are 43.1 percent that represent other factors that does not mention on this study, however it is proven that social media could not stand alone or self-sustain without the support from promotion though traditional media (Odhiambo, 2012).

\section{RECOMMENDATION}

There is some recommendation for the improvement of future researches, which going to be mentioned below:

1. In matter of promoting a destination, social media is not the only promotion tool, conventional media such as brochure, magazine or newspaper publish could also be used to promote a destination which opens to a possibility of different perspective outcome.

2. This research takes social media on a broad perspective, it is highly recommended to use one specific social media to assess how effective a social media platform (types), rather than assess social media at once.

3. In case of measuring Intention to visit to any destination, it is possible to use different independent variable that might give a greater insight of what factors that affect intention to visit. 


\section{REFERENCES}

Alexander, B. \& Levine, A. (2008). Storytelling Emergence of a New Genre.

AMEC. (2013). Framework announced - AMEC. [online] Available at: https://amecorg.com/2013/06/framework-announced/ [Accessed 25 Jul. 2017].

Balakrishnan, Dahnil, and Yi (2014). The Impact of Social Media Marketing Medium Toward Intention and Brand Loyalty Among Generation Y, Journal of Procedia - Social and Behavioral Sciences 00 (2012) 000-000.

Burke, J. \& Resnick, B.(2000). Marketing and Selling the Travel Product.2nd Edition ed. s.l.:Delmar Cengage Learning.

Brotherton, B. (2008), SAGE Researching Hospitality and Tourism a Student Guide Sage, Los Angeles, CA.

Chan, N. L. \& Guillet, B.(2011). Investigation of Social Media Marketing: How Does the Hotel Industry in Hong Kong Perform in Marketing on Social Media Websites?, Journal of Travel \& Tourism Marketing.

Eason, J. A. (2007).Online Social Networks: How Travelers Can Benefit From Using Interactive Sites.

Gärling, T., Gillholm, R. \& Gärling, A.(1998). "Reintroducing attitude theory in travel behavior research: The validity of an interactive interview procedure to predict car use". Transportation, 25(2), pp. 129-146.

Goeldner, C. R. \& Ritcie, J. B. (2012) . Tourism Principles, Practices, Philosophies. 12th Edition ed. Hoboken(New Jersey): John Wiley \& Sons Inc.

Hennessey, Sean M., Yun, Dongkoo, MacDonald R. (2016). Influencing the intention to visit a destination: the case of potential first-time and repeat visitors

Intyaswono, S., Yulianto, E. \& Mawardi, M. K. (2016). Peran Strategi City Branding Kota Batu Dalam Trend Peningkatan Kunjungan Wisatawan Mancanegara (Studi Pada Dinas Pariwisata dan Kebudayaan Kota Batu). Malang(East Java): Universitas Brawijaya.

Kaplan, A. M. \& Haenlein, M.(2010). Users of the World, Unite! The Challenges and Opportunities of Social Media. s.l.:Business Horizons.

Kennedy, G. et al.(2007). The Net Generation Are Not Big Users of Web 2.0 Technologies: Preliminary Findings. s.l.:Proceedings of Ascilite.

Királ'ová, A. \& Pavlíčeka, A.(2015). Development of Social Media Strategies in Tourism Destination. Social and Behavioral Sciences, Volume 175, p. $358-366$.

Kim, D.-Y., Y.-H. Hwang \& D.R. Fesenmaier (2005) Modeling Tourism Advertising Effectiveness. Journal of Travel Research, 2005: 44 (1): 42-9.

McWilliams, G.E., \& J.L. Crompton (1997) An Expanded Framework for Measuring the Effectiveness of Destination Advertising. Tourism Management, 18 (3): 127-37.

Messmer, D.J., \& R.R. Johnson (1993) Inquiry Conversion and Travel Advertising Effectiveness.Journal of Travel Research, 31 (4): 14-21.

Milhinhos, P. R. V. T.(2015). The impact of content marketing on attitudes and purchase intentions of online shoppers: the case videos \& tutorials and user-generated content.

Mirabi, D. V., Akbariyeh, H. \& T, H.(2015). A Study of Factors Affecting on Customers Purchase Intention. Journal of Multidisciplinary Engineering Science and Technology, 2(1), pp. 267273.

Odhiambo, C. A.(2012). Social media as a tool of marketing and creating brand awareness. Business Economics and Tourism.

Shah, H. et al.(2012). The Impact of Brands on Consumer Purchase Intentions. Asian Journal of Business Management, 4(2), pp. 105-110.

Sekaran, U., \& Bougie, R. (2013). Research methods for business : a skill building approach. West Sussex: John Wiley. 
Sweeney, S. \& Craig, R.(2011). Social Media for Business - 101 Ways to Grow Your Business Without Wasting Your Time.Maximum Press.

Theaker, A. (2016). The Public Relations Handbook. Abingdon: Taylor and Francis.

Thompson, S. K.(2012). Sampling. 3rd Edition ed. Hoboken(New Jersey): John Wiley and Sons, Inc.

Tuten, T. L.(2008). Advertising 2.0: Social media marketing in a Web 2.0. World

Vasiliu, C.(2007). Bune practici în domeniul transparenţei informaţiilor cazul Metro Group A. G.Amfiteatru Economic

Warschauer, M. \& Grimes, D.(2007). Audience, Authorship and Artifact: The Emergent Semiotics of Web 2.0.Annual Review of Applied Linguistics

Wells, A. T.(2008). "A Portrait of Early Internet Adopters: Why People First Went Online - and Why They Stayed," Washington, DC :Pew Internet \& American Life Project.

Widodo, D.(2017). Metodologi Penelitian Populer dan Praktis. DKI Jakarta: Rajawali Pers Divisi Buku Perguruan Tinggi

Woodside, A. G. (1996) Measuring the Effectiveness of Image and Linkage Advertising, Westport, CT: Quorum. 